Michał Biela

ORCID: 0000-0002-3426-8959

Uniwersytet Wrocławski

DOI: 10.19195/2450-274X.4.8

\title{
Teoretyczne założenia crowdfundingu oraz jego regulacje prawne w Unii Europejskiej i w Polsce
}

Abstrakt: Celem niniejszego artykułu jest prezentacja założeń teoretycznych oraz praktycznej implementacji koncepcji alternatywnych źródeł finansowania społecznościowego w Polsce i Unii Europejskiej ze szczególnym uwzględnieniem aspektów formalno-prawnych crowdfundingu.

Artykuł składa się z trzech części: w pierwszej opisano założenia definicyjne i koncepcyjne crowdfundingu, $w$ drugiej przedstawiono propozycję zmiany ram regulacyjnych finansowania społecznościowego, przygotowanych przez instytucje Unii Europejskiej, natomiast trzecia zawiera uregulowania prawne finansowania społecznościowego w Polsce.

W artykule jako metodę badawczą zastosowano desk research, której implementacja umożliwiła analizę istniejącej literatury przedmiotu.

Słowa kluczowe: crowdfunding, finansowanie społecznościowe, crowdsourcing, alternatywne finansowanie, platforma crowdfundingowa, regulacje unijne

Theoretical assumptions of crowdfunding and its legal regulations in the European Union and in Poland

Abstract: The aim of this article is to present the theoretical assumptions and practical implementation of the concept of alternative sources of funding in Poland and in the European Union, with emphasis on the formal and legal aspects of crowdfunding. The article consists of three parts. The first part describes the definition and conceptual assumptions of crowdfunding. The second part presents a proposal to change the crowdfunding regulatory framework at the European Union level. The third part includes legal regulations for crowdfunding in Poland. In the article, desk research was used as a research method, the implementation of which enabled the analysis of the existing literature on the subject.

Keywords: crowdfunding, funding of a crowd, crowdsourcing, alternative funding, crowdfunding platform, European Union regulations 


\section{Wstęp}

Crowdfunding może być traktowany jako jedna $\mathrm{z}$ instytucji ekonomii społecznej, która opiera się na procesie przepływu dóbr, takich jak pieniądze, pomysły oraz informacje, będących kluczowym elementem wczesnego etapu rozwoju różnego typu przedsięwzięć. System finansowania społecznościowego wykorzystuje „tłum” jako źródło pozyskiwania wymienionych zasobów oraz umożliwia w ten sposób utworzenie więzi na linii firma-klient, co sprzyja powstawaniu środowisk opartych na zbiorowym podejmowaniu decyzji ${ }^{1}$.

Nadrzędnym celem finansowania społecznościowego jest gromadzenie środków finansowych od osób zainteresowanych daną inicjatywą. Według Paula Belleflamme'a ${ }^{2}$ crowdfunding to system „otwartego dostępu” ( $\mathrm{z}$ ang. open call), który wykorzystuje platformy społecznościowe działające w charakterze pośrednika transferów środków finansowych w celu gromadzenia pieniędzy w postaci darowizn od osób fizycznych ${ }^{3}$. Dzięki temu możliwe jest finansowanie danego przedsięwzięcia w sposób otwarty, który nie ogranicza dostępu i jest adresowany do nieoznaczonego bliżej odbiorcy. William Cunningham określa finansowanie społeczne jako mechanizm pozwalający pozyskiwać pieniędze oraz informacje od ludzi, którzy postanowili przekazać część swoich pieniędzy jako darowiznę na rzecz rozwoju danego produktu 4 .

Artykuł ma na celu prezentację założeń teoretycznych alternatywnych źródeł finansowania społecznościowego w Polsce i Unii Europejskiej, ze szczególnym uwzględnieniem aspektów formalno-prawnych crowdfundingu. Obszar tematyczny prezentowanej tematyki obejmuje crowdfunding jako narzędzie gromadzenia kapitału inwestycyjnego oraz wsparcie jego rozwoju na europejskim rynku finansowania społecznościowego. Do celów badawczych sformułowana została hipoteza, zgodnie z którą finansowanie społecznościowe jako instrument alternatywnego finansowania jest skutecznym sposobem gromadzenia kapitału na rzecz rozwoju określonego przedsięwzięcia o charakterze biznesowym oraz prospołecznym na wczesnym etapie rozwoju. W celu weryfikacji tej hipotezy postawiono szczegółowe pytania badawcze:

1. Czym jest crowdfunding i związane z nim pojęcia (siatka terminologiczna) $\mathrm{w}$ świetle literatury przedmiotu?

2. Jakie dokumenty i programy unijne regulują kwestie w zakresie polityki odnośnie do crowdfundingu?

3. W jaki sposób crowdfunding określany jest przez krajowe regulacje prawne w Polsce?

${ }^{1}$ N. Scholz, The Relevance of Crowdfunding The Impact on the Innovation Process of Small Entrepreneurial Firms, Manchester 2015, s. 10.

2 P. Belleflamme, T. Lambert, A. Schwienbacher, Crowdfunding: Tapping the right crowd, „Journal of Business Venturing" 2014, s. 7-8.

${ }^{3}$ Ibidem.

${ }^{4}$ M. Cunningham, The JOBS Act. Crowdfunding for Small Businesses and Start-ups, New York 2012, s. 31-33. 
Przy pisaniu niniejszego artykułu wykorzystano następujące metody badawcze: metoda analizy materiałów źródłowych, opracowań dotyczących przedmiotu pracy i dokumentów prawnych umożliwiła uporządkowanie, a także wyeksponowanie i wyjaśnienie istoty poruszanych problemów. Artykuł oparto również na wynikach badań, które uzyskano dzięki zastosowaniu metody desk research, której implementacja umożliwiła analizę istniejącej literatury przedmiotu, jak również dokumentów unijnych oraz polskich. Efektem analizy desk research jest diagnoza stanu europejskiego prawa co do finansowania społecznościowego oraz opis i weryfikacja działań podejmowanych przez instytucje unijne na rzecz jego rozwoju.

\section{Założenia definicyjne i koncepcyjne crowdfundingu}

System finansowania społecznego, jakim jest crowdfunding, można uznać za potencjalne narzędzie do wspierania start-upów ${ }^{5}$. Możliwość rozproszenia ryzyka ponoszonych kosztów umożliwia hipotetycznemu pomysłodawcy podejmowanie śmielszych decyzji związanych z konkretnym projektem. Społeczność internetowa oraz podmioty gospodarcze za pomocą platform społecznościowych skupiają się wokół określonych inicjatyw, dzięki którym mogą realizować swoje pragnienia. Joachim Hemer podkreśla znaczenie wirtualnych platform, których zawartość generuje internetowa społeczność. Ten proces pozwala na lepiej zorientowany marketing oraz skraca czas gromadzenia funduszy ${ }^{6}$.

Aby lepiej poznać ideę crowdfunningu należy zrozumieć, czym jest crowdsourcing. Pierwszy raz termin crowdsourcingu został użyty przez Jeffa Howe’a oraz Marka Robinsona na łamach magazynu „Wired Magazine” w czerwcu 2006 r. ${ }^{7}$ Idea crowdsourcingu polega na wykorzystaniu pomysłów, propozycji, opinii, dzięki którym powstająca koncepcja, inicjatywa lub biznes mogą zawierać w sobie ofertę bardziej wszechstronną, zróżnicowaną oraz ukierunkowaną na szerszą grupę odbiorców, niekiedy zorientowaną na wyodrębnioną grupę docelowych klientów. Dzięki crowdsourcingowi przedsiębiorca może pozyskiwać informacje na temat swojego produktu w czasie rzeczywistym, na każdym etapie wprowadzanych zmian, co pozwala na wydajniejszą kontrolę towaru oraz efektu końcowego. Jest to wynikiem sprawnie przeprowadzonego procesu wymiany informacji na linii klient-firma. Proces ten może trwać przez cały okres prac nad danym produktem. W takim spo-

${ }^{5}$ Jest to nowo powstała organizacja nastawiona na szybkie gromadzenie kapitału, charakteryzująca się kreatywnym podejściem do biznesu.

${ }^{6}$ J. Hemer, A snapshot on crowdfunding, „Arbeitspapiere Unternehmen und Region” 2, 2011, s. $8-11$.

${ }^{7}$ R. Freund, How to overcome the barriers between economy and sociology with open innovation, open evaluation and crowdfund-ing?, „In International Journal of Industrial Engineering and Management" 1, 2010, nr 3, s. 105-109. 
sobie zarządzania biznesowego zmniejsza się rola ekspertów od marketingu oraz zmienia się sposób badania rynku. Podmioty angażujące się w kreowanie produktu dostarczają informacje pozwalające ocenić zainteresowanie inicjatywą. Inwestorzy pomagają promować projekt oraz budować społeczność związaną z daną inicjatywą, co pozwala na prowadzenie różnego typu działań marketingowych ${ }^{8}$.

Badanie aktywności zachowań inwestorów, przejawiających się przez transfery finansowe i recenzje produktu udostępniane na platformach crowdfundingowych, umożliwia badanie rynku i stopnia zainteresowania daną koncepcją przy niemal zerowych kosztach oraz przy użyciu niewielkiej ilości zasobów i czasu. Dzięki najbardziej zaangażowanym crowdfunderom środki zgromadzone we wczesnej fazie zbiórki można bezpośrednio wykorzystać na wydatki związane $\mathrm{z}$ marketingiem i usługami przedsprzedażowymi. Możliwość zamówienia produktu przed jego oficjalnym wejściem na rynek jest sposobem stworzenia więzi z potencjalnym fundatorem. Zaletą takiego podejścia jest jego innowacyjny, oddolny charakter, który sprzyja powstawaniu nowych rozwiązań ${ }^{9}$. Robert Freund uważa, że crowdfunding jest metodą, dzięki której możliwe będzie połączenie mechanizmów ekonomii z technikami socjologii. Badacz, opisując finansowanie społeczne jako sposób na finansowanie innowacji, nie ogranicza się jedynie do nowych form podejścia do biznesu. Według R. Freunda ekosystem wywodzący się z crowdsorcuingu może być sposobem na rozwiązanie wielu problemów społecznych i ekologicznych ${ }^{10}$.

Projekty crowdfundingowe muszą wzbudzać zainteresowanie oraz fascynację u odbiorców. Im większe zaangażowanie potencjalnych fundatorów, tym większe szanse na powodzenie projektu, ponieważ zwiększa się w ten sposób zainteresowanie publiczne. Crowdfunding pozwala zebrać środki pieniężne od zera, a tym samym wykonać projekt od podstaw. Umożliwia to mniej zamożnym przedsiębiorcom realizację swoich pomysłów, które nie miałyby szans zaistnieć w tradycyjny sposób, ponieważ inwestorzy typu Venture Capital ${ }^{11}$ oraz tzw. Anioły Biznesu ${ }^{12}$ skupiają się na jednostkach, które już posiadają wysoki kapitał własny ${ }^{13}$.

Jedną z najważniejszych funkcji crowdfundingu jest sygnalizacja, za pomocą której możliwe jest oszacowanie sukcesu innowacji. Przyporządkowana wartość wskazuje, że efekty sygnalizacyjne są klasyfikowane wyżej niż funkcja finansowa-

${ }^{8}$ D.T. Dziuba, Rozwój systemów crowdfundingu - modele, oczekiwania i uwarunkowania, „Problemy Zarządzania” 10, 2012, nr 3, s. 84-89.

9 P. Belleflamme, T. Lambert, A. Schwienbacher, op. cit., s. 5-12.

10 R. Freund, op. cit., s. 105-109.

11 Jest to forma finansowania wspierająca początkujące przedsięwzięcia biznesowe wykazujące duży potencjał rozwoju. Venture Capital zapewnia wsparcie w prowadzeniu biznesu oraz zarządza środkami innych kapitałodawców. Zazwyczaj obarczone jest wysokim ryzykiem.

$12 \mathrm{Z}$ ang. business Angel - prywatny inwestor, inwestujący kapitał własny w początkujące przedsięwzięcia biznesowe, jak start-upy, w zamian za udziały w tym przedsięwzięciu.

${ }^{13}$ J. Hemer, op. cit., s. 28; K. Mazurek-Łopacińska, M. Sobocińska, Crowdsourcing i crowdfunding $w$ kreowaniu innowacji $w$ konsumpcji, „Studia i Prace Wydziału Nauk Ekonomicznych i Zarządzania" 2, 2016, nr 43, s. 180-182. 
nia. Dlatego też, biorąc pod uwagę sprawdzone zainteresowanie rynku kampanią, pomysły wydają się atrakcyjniejsze dla inwestorów. Crowdfunding jest także narzędziem finansowym wstępnych działań wdrożeniowych produktu, analizy ryn$\mathrm{ku}$, zgłoszenia patentu, a także profesjonalnego doradztwa. Funkcja przedsprzedaży może skracać proces innowacyjny, dlatego też jest szczególnie ważna przy udzielonej obietnicy nagrody sponsorom. $Z$ tego powodu mechanizm przedsprzedaży wykazuje duży potencjał przy planowaniu kolejnych etapów inwestycji14.

Postęp technologiczny, a w szczególności rozwój Web $2.0^{15}$, wykształcił wirtualną przestrzeń, w której platformy społecznościowe dzięki swojej formie i strukturze pozwalają wchodzić użytkownikom w interakcje. Platformy crowdfundingowe umożliwiają nieustanną wymianę informacji przez inwestorów będących w interakcji z realizatorami projektów. Takie podejście pozwala zmaksymalizować efekty pracy oraz skrócić czas, który potrzebny jest na pozyskanie informacji. Platformy te są również bezpiecznym pośrednikiem w wymianie transferów finansowych ${ }^{16}$.

W literaturze przedmiotu wymienia się trzy typy uczestników finansowania społecznościowego. Pierwszy typ to pomysłodawcy, których głównym celem jest gromadzenie wsparcia finansowego od ich zwolenników. Drugim jest „tłum” ( $\mathrm{z}$ ang. crowd), czyli grupa zaangażowanych ludzi, którzy decydują się dobrowolnie wspierać finansowo potencjalną inicjatywę. Fundatorzy w zależności od swojego wkładu ponoszą ryzyko, które może zostać wynagrodzone w sposób materialny lub wirtualny. Niekiedy dotacja ma swoisty wymiar ideowy i w takiej sytuacji nagrodą jest satysfakcja lub sam udział $\mathrm{w}$ danej inicjatywie. Trzecim typem uczestnika finansowania społecznego są platformy finansowania społecznościowego pełniące funkcje pośrednika łączącego potencjalnych zwolenników z inicjatorami przedsięwzięć crowdfundingowych ${ }^{17}$.

Benjamin Larralde i Armin Schwienbacher zaznaczają, że istotnym elementem finansowania społecznościowego jest jego oddolny charakter. Objawia się to tym, że główną grupą zaangażowaną $\mathrm{w}$ finansowanie projektu są zwykli ludzie, a nie profesjonalne podmioty związane z sektorem bankowym czy inwestycyjnym. Dostrzega się, że crowdfunding jako proces świetnie wykorzystuje mechanizm dezintermediacji ${ }^{18}$ oraz wskazuje się ważną rolę internetowych platform pośredniczących, bez których wymiana myśli i kapitału nie byłaby możliwa ${ }^{19}$.

${ }^{14}$ N. Scholz, op. cit., s. 7-10.

15 Termin używany do określania serwisów internetowych powstających po 2001 r., których treść tworzą użytkownicy.

16 E. Gerber, P.Y. Kuo, Design principles. Crowdfunding as a creativity support tool, [w:] Proceeding CHI '12 Extended Abstracts on Human Factors in Computing Systems, New York 2012, s. 1601-1606.

17 A. Ordanini et al., Crowdfunding: Transforming customers into investors through innovative service platforms, „In Journal of Service Management” 22, 2011, nr 4, s. 443-470.

18 W ekonomii eliminowanie pośredników z działu świadczonych usług, np. przez tworzenie stron internetowych.

19 B. Larralde, A. Schwienbacher, Crowdfunding of small entrepreneurial ventures, „Handbook of Entrepreneurial Finance" New York 2012, s. 4-7. 
Należy podkreślić znaczenie istoty internetu, dzięki której finansowanie społecznościowe nie tylko może mieć miejsce, lecz także może nabierać dynamicznego tempa rozwoju. Internet jest obszarem wszelkich interakcji związanych $\mathrm{z}$ crowdfundingiem. To tutaj rozpoczyna się pierwszy i ostatni etap związany z gromadzeniem funduszy na daną inicjatywę. Kluczowym elementem crowdfundingu jest niski próg wejścia, nazywany „otwartym zaproszeniem”. Praktycznie każdy podmiot, który identyfikuje się z daną inicjatywą lub wyraża chęć uczestnictwa, może zostać fundatorem.

Finansowanie społecznościowe przez swój szeroki wachlarz zastosowań określane jest terminem parasolowym. Crowdfunding dzieli się na różne typy ze względu na bazowy cel przedsięwzięcia. B. Larralde i A. Schwienbacher uważają, że znaczna część inicjatyw związanych z finansowaniem społecznym oparta jest na gromadzeniu funduszy w postaci darowizn. Badacze przypominają, że „maksymalizacja zysków często idzie w parze ze znormalizowanymi produktami o niższej jakości, podczas gdy organizacje non profit są bardziej skłonne do wytwarzania produktów wysokiej jakości” ${ }^{20}$. W przedstawionej sytuacji „tłum”, który stanowi niezorganizowaną, często przypadkową grupę ludzi w internecie, będzie bardziej zainteresowany ofertą organizacji non profit, która będzie wytwarzać produkty wysokiej jakości. W takim rodzaju crowdfundingu fundatorzy nie oczekują wynagrodzenia w kategoriach fizycznych czy finansowych, ponieważ zaspokojone zostały ich pragnienia społeczne.

Kolejnym typem są inwestycje pasywne - rodzaj finansowania społecznego, który polega na metodzie przyciągania inwestorów, oferując pewien rodzaj gratyfikacji. Larralde i Schwienbacher zaznaczają, że wkład fundatorów w daną inicjatywę sprowadza się jedynie do wsparcia finansowego. Przedsiębiorca, wybierając ten model crowdfundingu, nie korzysta $\mathrm{z}$ innego wsparcia ze strony „tłumu”.

Ostatnim rodzajem są inwestycje aktywne, które polegają na oferowaniu korzyści w zamian za udział w przedsięwzięciu. Przedsiębiorca otrzymuje środki finansowe oraz informacje zwrotne na temat produktu ${ }^{21}$.

Finansowanie społecznościowe opiera się na różnych podejściach biznesowych $\mathrm{z}$ racji występowania wielu grup potencjalnych inwestorów. Ethan Mollick uważa, że klientów można dopasować do odpowiedniego modelu finansowania społecznościowego po wcześniejszej identyfikacji ich motywacji ${ }^{22}$.

J. Hemer uzasadnia powstanie wielu modeli finansowania społecznego jako odpowiedzi na potrzeby różnych projektów. Tym, co pozwala dokonać rozróżnienia w modelach finansowania społecznościowego, jest charakter przedsięwzięcia oraz główny cel projektu. Inicjatywy nienastawione na zysk Hemer opisuje jako projekty, które są ważne z punktu widzenia społeczeństwa. Takie cele mogą zostać

20 Ibidem, s. 5.

${ }^{21}$ Ibidem, s. 8-12.

22 E. Mollick, Swept Away by the Crowd? Crowdfunding, Venture Capital, and the Selection of Entrepreneurs, Pennsylvania 2013, s. 12-15. 
spełnione poprzez gromadzenie funduszy na rzecz publicznych projektów badawczych, akcji charytatywnych, rozwoju infrastruktury regionalnej lub lokalnej czy pomocy rozwojowej danych podmiotów działających na rzecz społecznego dobra. Z kolei koncepcje o podłożu czysto komercyjnym, czyli takie, których przeznaczeniem jest maksymalizacja dochodów, wykorzystują siłę crowdfundingu w celach m.in. promowania nowych produktów, finansowania komercyjnego przedsięwzięcia, np. filmu lub płyty muzycznej, pomocy przy zakładaniu firmy, itp. Hemer zauważa również, że istnieją projekty pośrednie, które ciężko jednoznacznie określić, ponieważ nie zawsze jesteśmy świadomi ich ostatecznego kształtu. Przez projekty pośrednie możemy rozumieć takie koncepcje czy idee, które mogą spełniać rolę społeczną i komercyjną. Przykładem może być zespół muzyczny działający na scenie lokalnej, który poszukuje funduszy na wydanie swojej pierwszej płyty. Sama chęć wydania płyty ma dla zespołu podłoże czysto komercyjne, jednak dla społeczności lokalnej może mieć również wymiar kulturowy, ponieważ w ramach rekompensaty zespół może zadeklarować swój udział w działaniach, których celem jest promowanie miasta. Takie wejście we wzajemną interakcję pomaga budować lokalne więzi, które są podstawą lokalnych relacji międzyludzkich ${ }^{23}$.

Według Belleflamme’a dzięki crowdfundingowi łatwiej jest osiągnąć swoje cele finansowe niż z pomocą innych organizacji non profit. Wynika to z faktu, że organizacje crowdfundingowe przyciągają więcej darczyńców, ponieważ nie skupiają się tylko na środkach pieniężnych ${ }^{24}$.

Dla wskazania różnic między oryginalną wbudowaną strukturą organizacyjną crowdfunding można podzielić na trzy podejścia. Niezależne i pojedyncze projekty, które tworzone są przez podmiot niemający specjalistycznego zaplecza oraz niebędący częścią większej całości, np. przedsiębiorstwa większego projektu; „wbudowane projekty" (z ang. embedded projects) będące częścią organizacji, przez którą zostały zapoczątkowane; start-upy, które zazwyczaj powstają jako niezależne projekty zmierzające do osiągnięcia statusu organizacji o nieograniczonym zakresie ${ }^{25}$.

W celu wyodrębnienia rodzajów crowdfundingu Hemer proponuje następujące terminy ${ }^{26}$ : pierwszym są darowizny „tłumu” ( $\mathrm{z}$ ang. crowd donations), czyli zachowania altruistyczne, w których darczyńca nie uzyskuje korzyści; drugim jest sponsorowanie "tłumu” (z ang. crowd sponsoring), gdzie inicjatorzy są zobligowani do przekazania korzyści sponsorom; trzecim są „tłumy” przedsprzedażowe ( $\mathrm{z}$ ang. crowd pre-selling), które pomagają $\mathrm{w}$ produkcji określonych przedmiotów; czwartym są pożyczki „tłumu” ( $\mathrm{z}$ ang. crowd lending), które określa się czasem kredytowania i zapłaconych odsetek; oraz piąty typ - inwestowanie „tłumu” (z ang. crowd investing), który jest najbardziej obciążony administracyjnie. Crowdfunde-

\footnotetext{
23 J. Hemer, op. cit., s. 15-17.

${ }^{24}$ P. Belleflamme, T. Lambert, A. Schwienbacher, op. cit., s. 5-7.

25 Ibidem.

${ }^{26}$ J. Hemer, op. cit., s. 13-14.
} 
rzy mogą uzyskać akcje, dywidendy lub prawa głosu. Kaufmann ${ }^{27}$ nazywa ten typ „podnoszeniem tłumu” (z ang. crowd rising), gdzie potencjalne zyski są klasyfikowane jako nieoprocentowane obligacje, które zapewniają zwrot wkładu początkowego, ale nie gwarantują zwrotu $\mathrm{z}$ inwestycji, lub akcje, dzięki którym można odzyskać zainwestowane środki ${ }^{28}$.

Należy uznać, że crowdfunding ma co najmniej dwie podstawowe funkcje ekonomiczne: przedsprzedaż oraz dzielenie zysków. Przedsprzedaż jest używana przez przedsiębiorców, aby zachęcić konsumentów do wcześniejszego kupna, co umożliwi im zebranie kapitału potrzebnego do uruchomienia produkcji. Dzięki przedsprzedaży przedsiębiorcy są $\mathrm{w}$ stanie wyodrębnić crowdfunderów, którzy są gotowi nabyć produkt wcześniej, od zwykłych konsumentów, którzy czekają z zakupem, aż produkt wejdzie na rynek ${ }^{29}$. Natomiast w systemie dzielenia zysków przedsiębiorcy zabiegają o zapewnienie środków finansowych, oferując w zamian udział w zyskach generowanych w przyszłości. Niektóre firmy, np. Wefunder ${ }^{30}$ oraz Localstake ${ }^{31}$, zachęcają do kupna papierów wartościowych.

W obu przypadkach crowdfunderzy czerpią większe korzyści od przeciętnych konsumentów oraz uzyskują dodatkowe korzyści społeczne, które mogą się różnić $\mathrm{w}$ zależności od formy crowdfundingu. $\mathrm{Z}$ mechanizmem dzielenia zysków wiążą się doświadczenia inwestycyjne, a $\mathrm{z}$ przedsprzedażą doświadczenia związane z konsumpcją, co z kolei może wpływać na wybór formy finansowania przez przedsiębiorców.

Według Bellaflame’a przedsiębiorcy skłaniają się ku przedsprzedaży, gdy wymóg kapitałowy jest niewielki i preferują podział zysków, gdy wymóg kapitałowy jest duży, ponieważ system podziału zysków jest bardziej opłacalny przy większych kwotach.

Konsumenci, dla których konsumpcja dóbr jest korzystniejsza, są gotowi zapłacić więcej niż klienci, którzy będą czekać, aż produkt będzie dostępny na rynku po niższej cenie.

Przedsiębiorcy wolą, kiedy inwestycje są opłacane wcześniej przez wkład inwestorów, nawet jeśli mniej osób miałoby zakupić produkt. Jest to spowodowane tym, że przy metodzie dzielenia zysków świadczenia wspólnotowe są łatwiejsze do opodatkowania $^{32}$.

System dzielenia zysków może przypominać darowizny w przypadku, gdy crowdfunderzy nie dzielą się zyskiem z przedsiębiorcą (jak na przykład Fundly.

27 Fundacja Ewinga Mariona Kauffmana jest organizacją non profit, koncentrującą się na projektach promujących przedsiębiorczość i wspierających edukację.

28 T. Alberg et al., State of entrepreneurship adress: 'Financing entrepreneurial growth', „SSRN Electronic Journal" 02.2013.

29 P. Belleflamme, T. Lambert, A. Schwienbacher, op. cit., s. 2-3.

$30 \mathrm{https} / / /$ wefunder.com/ (dostęp: 21 października 2019).

$31 \mathrm{https} / / /$ localstake.com/ (dostęp: 21 października 2019).

32 Ibidem. 
com). Kiedy korzyści społecznościowe są duże, przyszli crowdfunderzy mają możliwość finansowania projektu, dzięki czemu będzie on kontynuowany. Darowizny są przekazywane przez crowdfunderów, ponieważ oczekują oni dodatkowych korzyści społecznych, co jest sprzeczne z definicją darowizny. W ten sposób dostęp do darowizn mają nie tylko organizacje non profit ${ }^{33}$.

Wybór crowdfundingu jako sposobu finansowania znacznie wpływa na rozwój projektu, zwłaszcza w jego początkowej formie. Wiąże się to z potrzebą organizacji internetowych sieci społecznościowych, które umożliwią kontakt $\mathrm{z}$ „tłumem”. Tworzenie więzi z „tłumem” odgrywa elementarną rolę, ponieważ pomaga w uzyskaniu zasobów finansowych, a także innowacyjnych. W niektórych przypadkach „tłum” może wpływać na decyzje podejmowane przy projekcie. W obu formach finansowania więź, która łączny projekt $\mathrm{z}$ „tłumem”, może generować większe korzyści niż tradycyjne finansowanie. Dzieje się tak, ponieważ dyskryminacja cenowa sprzyja ekspansji rynku34.

\section{Propozycja ram regulacyjnych na poziomie unijnym}

Komisja Europejska w dokumencie Legislative proposal for an EU framework on crowd and peer to peer finance ${ }^{35} \mathrm{z} 10$ października 2017 r. przedstawiła propozycję wspólnych ram prawnych dla finansowania społecznościowego. Działania mają na celu wzmocnienie znaczenia rożnych źródeł finansowania alternatywnego, w tym finansowania społecznościowego. Regulacje wypracowane drogą porozumienia powinny w sposób jasny i klarowny zabezpieczyć rynek finansowania i tym samym umożliwić tworzenie nowych miejsc pracy oraz pomoc istniejącemu już sektorowi związanemu z MŚP. W dokumencie poruszono również kwestię wprowadzenia środków ochrony inwestorów.

Komisja w periodycznej rewizji planu działania w obrębie Unii Rynków Kapitałowych w roku 2017 miała ocenić, jaka metoda technologii finansowania (FinTech) dałaby możliwość pogłębienia i rozwoju rynków kapitałowych UE, jednocześnie oferując inwestorom zróżnicowane opcje i otwierając perspektywę rozwoju alternatywnych rynków finansowych. Obecnie plan działania stara się spożytkować cały potencjał FinTech w celu zapewnienia odbiorcom lepszych usług finansowych oraz udogodnienia dostępu do źródeł finansowania za granicą, równocześnie zapewniając konsumentom wysoki poziom ochrony.

\footnotetext{
${ }^{33}$ Ibidem.

34 K.D. Miller, F. Fabian, S.-J. Lin, Strategies for online communities, „Strategic Management Journal" 30, 2009, s. 305-322.

35 European Commission, Legislative proposal for an EU framework on crowd and peer to peer finance, Brussels 2018, https://ec.europa.eu/info/law/better-regulation/initiatives/ares-2017-5288649_ en (dostęp: 29 sierpnia 2018).
} 
Inicjatywa ma na celu rozwiązanie problemu, jakim jest fragmentacja rynku polegająca na zróżnicowanej ochronie prawnej w poszczególnych krajach Unii Europejskiej. Komisja Europejska wskazuje, że różnice w przepisach krajowych mogą determinować niski poziom działań na poziomie transgranicznym oraz powodować wyższe koszty takich operacji. Aktywność platform crowdfundingowych nadal w dużej mierze ogranicza się do rynku krajowego ${ }^{36}$.

Zróżnicowany system prawny hamuje rozwój platform crowdfundingowych, przez co te nie mogą świadczyć usług $\mathrm{w}$ pełnym zakresie swoich możliwości, na obszarach dla nich atrakcyjnych. Wyrazem tego jest fakt, że wiele platform nie świadczy usług dla nierezydentów, co wpływa na jakość oraz ilość potencjalnych inwestycji. Przez brak ujednoliconego prawa część platform finansowania społecznościowego opiera swoją działalność jedynie na rynku krajowym, tym samym zamykając się w znacznym stopniu na interakcje o wymiarze transgranicznym ${ }^{37}$.

Kolejną kwestią jest niezawodność platform crowdfundingowych. Brak pełnego zaufania oraz rzetelności ze strony platform crowdfundingowych jest uważany za możliwe ryzyko dla przyszłego rozwoju finansowania społecznościowego. Przykładem mogą być nadużycia, nieuczciwa aktywność, niewypłacalność oraz upadek platform, a także problemy związane $\mathrm{z}$ bezpieczeństwem danych klientów i wykorzystanie crowdfundingu do celów niezgodnych z prawem. Problemem jest również deficyt informacji, który utrudnia inwestorom podjęcie w pełni świadomej decyzji związanej z potencjalnym ryzykiem inwestycji. Komisja Europejska wskazuje również, że nie istnieją wymagania, które zmuszałyby do jawności ofert świadczonych za pośrednictwem platform finansowania społecznościowego ${ }^{38}$.

Podstawą prawną, na której Komisja opierałaby dalsze prace ustanawiające ramy crowdfundingu, jest art. 114 Traktatu o funkcjonowaniu Unii Europejskiej (TFUE). Głównym celem byłoby wprowadzenie zmian na rynkach krajowych w taki sposób, aby platformy crowdfundingowe mogły rozwijać się na jednolitym rynku.

Dzięki dotychczasowym działaniom Komisji Europejskiej ${ }^{39}$ niektóre państwa członkowskie Unii Europejskiej postanowiły tak dostosować ramy krajowe co do finansowania społecznościowego, aby pokrywały się z zaleceniami Komisji. Jednak zasadniczo nadal nie rozwiązało to problemu na poziomie transgranicznym, a jedynie pozwoliło ujednolicić prawo w pewnych kwestiach. W dalszym ciągu problemem, mimo pewnego stopnia spójności w zakresie celów czy rezultatów krajowych ram prawych, jest ich dostosowanie jedynie do rynków na poziomie

36 Ibidem.

37 B. Zhang et al., Sustaining momentum: The 2nd European Alternative Finance Industry Report, Cambridge 2016, s. 24-28.

38 Ibidem.

39 Komisja, spotykając się dwa razy w roku, prowadzi regularny dialog z europejskimi organami nadzoru, państwami członkowskimi i sektorem finansowania społecznościowego w celu promowania konwergencji, wymiany najlepszych praktyk i monitorowania zmian na rynku. 
lokalnym oraz krajowym. Nowe przepisy, które chce wdrożyć UE, realnie pomogłyby stworzyć obszar dla jednolitego rynku opartego na wspólnych ramach prawnych w zakresie finansowania społecznościowego. Uregulowanie tych kwestii na poziomie ponadnarodowym nie tylko przyczyniłoby się do przezwyciężenia następstw, które są wynikiem obecnego niedopracowanego i niejednolitego systemu prawnego, lecz także prowadziłoby do rozwoju większego rynku transgranicznego, tym samym stwarzając warunki do opłacalnego i bezpiecznego sposobu korzystania $\mathrm{z}$ instrumentów, jakie oferuje crowdfunding.

Celem inicjatywy jest wsparcie i rozwój ekosystemu, jakim jest crowdfunding, dzięki wykorzystaniu jednolitego rynku. Poprzez szereg udogodnień związanych z nowymi wytycznymi Komisja Europejska chce osiągnąć stan, który przyczyni się do osiągnięcia założeń w ramach planu działań Unii Rynków Kapitałowych.

Aby platformy finansowania społecznościowego mogły w efektywny i bezpieczny sposób świadczyć swoje usługi na poziomie transgranicznym, potrzebne jest wykształcenie norm oraz obszaru uwarunkowania o pewnych specyficznych cechach, które będą umożliwiały stosowanie jednolitego systemu prawnego na terenie całej UE bez konieczności uzyskania dodatkowego zezwolenia w każdym kraju UE. Działania UE będą opierać się na stworzeniu systemu licencjonowania, który będzie bazować na takich samych zasadach na terenie całej Unii Europejskiej. Wypracowanie takiej normy pozwoli zwiększyć ilość inwestycji w ramach finansowania społecznościowego oraz zmniejszy koszty transakcji ${ }^{40}$.

Komisja Europejska wskazuje, że rozwój crowdfundingu na poziomie transgranicznym wymaga dużego poziomu zaufania. Opracowanie dopasowanego i skutecznego systemu zarządzania ryzykiem dostarczy inwestorom należytych informacji w odniesieniu do zasad dotyczących natury działania platform. Istotne jest również opracowanie jednolitego podejścia do zagrożeń takich jak ochrona danych osobowych i cyberbezpieczeństwo, co w znacznym stopniu zwiększy zaufanie ${ }^{41}$.

Do oceny skutków zastosowano analizę, w której Unia Europejska skupia się na przedstawieniu możliwych scenariuszy ${ }^{42}$. Przy założeniu, że Unia Europejska nie zdecyduje się wprowadzić ram prawnych na poziomie ponadnarodowym, Komisja Europejska zakłada stały dialog, spotykając się dwa razy w roku, jak miało to miejsce dotychczas. W dialog miałyby być zaangażowane państwa członkowskie, europejskie organy nadzoru i sektor finansowania społecznościowego. Taki scenariusz zakłada sytuację, w której państwa członkowskie wdrażają samoistnie dostosowane do potrzeb systemy finansowania społecznościowego normy.

Wariant drugi zakłada zalecenia ze strony Komisji Europejskiej, poprzez mapowanie oraz wskazywanie najlepszych rozwiązań systemowych w celu wykształ-

40 Commision Staff Working dokument, Crowdfunding in the EU Capital Markets Union, Brussels 2016, https://ec.europa.eu/transparency/regdoc/rep/10102/2016/EN/10102-2016-154-EN-F1-1.PDF (dostęp: 29 sierpnia 2018).

${ }^{41}$ Ibidem.

42 European Commission, op. cit. 
cenia nieformalnych, minimalnych standardów oraz zasad dotyczących praktyk związanych z crowdfundingiem.

Wariant trzeci to kompleksowe podejście Unii Europejskiej do sposobu uregulowania platform finansowania społecznościowego. Komisja Europejska wprowadziłaby licencje, na których opierałaby się działalność platform crowdfundingowych w ramach jednolitego rynku. Takie rozwiązanie pozwoliłoby zapewnić większą ochronę inwestorom oraz zwiększyłoby przejrzystość funkcjonowania platform crowdfundingowych. Celem jest harmonizacja systemów krajowych poprzez utworzenie odrębnego prawodawstwa przy jednoczesnym wykorzystaniu wybranych przepisów $\mathrm{UE}^{43}$.

Ostatni wariant zakłada, że Komisja stworzy system, w którym platformy crowdfundingowe będą mogły zdecydować, w jakim porządku prawnym chcą prowadzić swoją działalność. Głównym celem jest zwiększenie skali działalności platform poprzez passporting ${ }^{44}$ oraz stworzenie takich wymogów organizacyjnych, które zapewnią ochronę podmiotom biorącym udział w projektach crowdfundingowych ${ }^{45}$.

Głównym celem komisji UE jest utworzenie ram prawnych adekwatnych do rzeczywistości europejskiego rynku finansowania społecznościowego. Komisja Europejska zdaje sobie sprawę $\mathrm{z}$ dynamicznej natury crowdfundingu, dlatego regulacje powinny opierać się na prostych i proporcjonalnych założeniach, z uwzględnieniem obecnych trendów panujących na rynkach finansowych.

Komisja Europejska przewiduje, że wprowadzenie unijnych ram finansowania społecznościowego może przynieść następujące skutki ekonomiczne ${ }^{46}$ :

- crowdfunding przyczyni się do wprowadzania innowacji, umożliwi większą selekcję inwestorów, podwyższy konkurencję na rynkach detalicznych i kapitałowych, a także będzie mógł zapewniać inwestorom dostęp do większych źródeł informacji i przyciągać inne formy finansowania;

- do przewidywanych skutków w aspekcie społecznym należy zaliczyć większy dostęp finansowania dla MŚP oraz przedsiębiorstw typu start-up, dzięki zwiększeniu rynku w wymiarze transgranicznym. To z kolei może pozytywnie wpłynąć na wzrost gospodarczy w Europie, a w szczególności na liczbę miejsc pracy;

- unijne ramy finansowania społecznościowego mogą sprawić, że osoby inwestujące swoje środki w crowdfunding będą miały dostęp do szczegółowych informacji na temat przedsięwzięcia, w które się angażują, co prowadzi do usprawnienia przepływu informacji do opinii publicznej.

Inicjatywa ma umożliwić aktywne inwestowanie i udział w rynku kapitałowym świeżym, innowacyjnym podmiotom gospodarczym. Finansowanie społeczno-

${ }^{43}$ Ibidem.

44 Prawo do prowadzenia działań finansowych w Europejskim Obszarze Gospodarczym.

45 European Comission, Executive Summary: Identifying market and regulatory obstacles to cross-border development of crowdfunding in the EU, 2017, https://ec.europa.eu/info/sites/info/ files/171216-crowdfunding-executive-summary_en.pdf (dostęp: 2 września 2018).

46 Sustaining momentum: The 2nd European Alternative... 
ściowe zapewni dostęp do szerszego grona inwestorów oraz umożliwi korzystanie z innych instrumentów gromadzenia kapitału, nie bazując jedynie na tradycyjnych formach finansowania bankowego. Regulacje na poziomie unijnym pozwolą obniżyć koszty wynikające z różnorodności systemów krajowych. Ważnym celem jest usprawnienie sektora administracyjnego, aby operatorzy platform mogli uniknąć dodatkowych kosztów i formalności związanych z prowadzeniem działalności poza granicami własnego państwa ${ }^{47}$.

\section{Uregulowania prawne finansowania społecznościowego w Polsce}

W Polsce nie istnieje jednoznaczny system regulacyjny odnośnie do crowdfundingu. W 2014 r. polski rząd postanowił, że ze względu na wczesny etap rozwoju oraz małą skalę zjawiska crowdfunding w Polsce nie wymaga wprowadzania nowych regulacji prawnych. Dlatego też podstawową regulacją pozostaje kodeks cywilny. Podkreślono jednak, że wraz z rozwojem crowdfunding może przyjąć odmienne formy, które będą wymagały osobnych regulacji ${ }^{48}$.

W 2015 r. podczas konferencji „Innowacyjna Europa” Koalicja na rzecz Polskich Innowacji ${ }^{49}$ zaprezentowała projekt ustawy regulującej działanie crowdfundingu inwestycyjnego. Do głównych założeń projektu należy zniesienie obciążeń regulacyjnych dotyczących systemów ofert publicznych oraz usług płatniczych, a także handlu instrumentami finansowymi ${ }^{50}$.

Niektóre rodzaje crowdfundingu mogą wymuszać stosowanie przepisów finansowych. Jedną z ustaw, która może dotyczyć polskich założycieli platform crowdfundingowych, jest ustawa o handlu instrumentami finansowymi z 29 lipca 2005 r. ${ }^{51}$, która jest implementacją unijnej dyrektywy w sprawie rynków instrumentów finansowych z kwietnia 2004 r. Ustawa ta może obowiązywać platformy opierające swoją działalność na udziałach, jak np. spółki akcyjne czy komandytowo-akcyjne, w przypadku gdy akcje spółki będą kwalifikowane jako instrument finansowy oraz działania platformy zostaną uznane za usługi inwestycyjne. W rozumieniu ustawy regulacjom podlega pośrednictwo w obrocie instrumentami finansowymi oraz oferowanie związanych $\mathrm{z}$ tym usług. Spółka z o.o. nie będzie regulowana przez tę ustawę, ponieważ jej udziały nie są uznawane za papiery wartościowe. Dlatego też

47 T. Ziegler et al., Expanding horizons: The 3rd European Alternative Finance Industry Benchmarking Report, Cambridge 2016, s. 38-40.

48 Review of Crowdfunding Regulation 2017. Interpretations of existing regulation concerning crowdfunding in Europe, North America and Israel, red. O. Gajda, Brussels 2017.

49 Jest to międzysektorowa sieć działająca w celu polepszenia warunków dla rozwoju innowacji w Polsce, https://koalicjadlainnowacji.pl/ (dostęp: 15 października 2018).

50 https://koalicjadlainnowacji.pl/publikacje/ (dostęp: 15 października 2018).

51 Ustawa z dnia 29 lipca 2005 r. o obrocie instrumentami finansowymi (Dz.U. z 2005 r. Nr 183, poz. 1538). 
ważnym krokiem jest ustalenie, czy platforma posiłkuje się działaniami maklerski$\mathrm{mi}$, co jest równoznaczne ze świadczeniem usług inwestycyjnych ${ }^{52}$.

Instrumentem prawnym mającym istotne znaczenie dla polskich crowdfunderów jest zapis art. 171 ust. 1 dotyczący Prawa bankowego ${ }^{53}$. Wyznacza on obowiązek posiadania zezwolenia na prowadzenie działalności polegającej na udzielaniu kredytów i pożyczek z funduszy zebranych od innych organizacji lub od osób fizycznych. Ustawa ta może dotyczyć w szczególności platform crowdfundingowych opierających swoją działalność na kredytach, ponieważ może to zostać zakwalifikowane jako działalność bankowa, która wymaga zezwolenia. W celu uniknięcia niepotrzebnych obciążeń crowdfunderzy mogą ograniczyć swoją działalność jedynie do pośredniczenia między inwestorami a beneficjentami.

Jednocześnie ustawa o ofercie publicznej i warunkach wprowadzania instrumentów finansowych do zorganizowanego systemu obrotu oraz ustawa o ofercie publicznej zobowiązują crowdfunderów do przygotowania i publikacji prospektu emisyjnego, który musi zostać zaakceptowany przez KNF. Wiele platform prowadzi swoją działalność w taki sposób, aby wartość prowadzonego projektu nie przekraczała podstawowego progu prospektu emisyjnego, który wynosi w Polsce 100 tys. euro w skali roku. Wymóg ten nie dotyczy spółek z o.o.

Właściciele platform crowdfundingowych mogą prowadzić swoją działalność $\mathrm{w}$ formie funduszu inwestycyjnego lub alternatywnego funduszu inwestycyjnego, na zasadach określonych w ustawie o funduszach inwestycyjnych z 27 maja 2004 r. ${ }^{54}$ Natomiast ta ustawa nie będzie obowiązywała platform crowdfundingowych, których działalność opiera się na start-upach ${ }^{55}$.

Platformy crowdfundigowe pośredniczą w przekazywaniu środków między podmiotami finansującymi a beneficjentami. Takie czynności mogą podlegać regulacji z tytułu ustawy o usługach płatniczych z 19 sierpnia 2011 r. ${ }^{56}$, która wymaga uzyskania zgody na świadczenie usług płatniczych. Większość crowdfunderów korzysta $\mathrm{z}$ wyjątku określonego w art. 6 pkt 2 ustawy, który zakłada, że ustawa ta nie obowiązuje transakcji płatniczych dokonywanych za pośrednictwem podmiotu wykonującego, mającego na celu doprowadzenie do zawarcia umowy między podmiotem finansującym a beneficjentem.

Dnia 2 kwietnia 2018 r. w Polsce weszła w życie nowelizacja ustawy o usługach płatniczych - PSD2. Kluczowym aktem prawnym uzupełniającym PSD2 jest RTS (ang. Regulator Technical Standards), który ma zapewnić bezpieczne standardy komunikacji oraz innowacyjne standardy uwierzytelniania klienta. Projekt zobliguje

\footnotetext{
52 L. Marcinoska et al., Raport: Crowdfunding, Warszawa 2014.

53 Art. 171. Odpowiedzialność karna za prowadzenie działalności wbrew przepisom ustawy. Art. 171 ust. 6 zmieniony ustawą z dnia 21 lipca 2006 r. (Dz.U. Nr 157, poz. 1119).

54 Ustawa z dnia 27 maja 2004 r. o funduszach inwestycyjnych i zarządzaniu alternatywnymi funduszami inwestycyjnymi (Dz.U. z 2004 r. Nr 146, poz. 1546).

55 Review of Crowdfunding Regulation 2017...

56 Ustawa z dnia 19 sierpnia 2011 r. o usługach płatniczych (Dz.U. z 2011 r. Nr 199, poz. 1175).
} 
dostawców usług płatniczych do utworzenia dedykowanego interfejsu komunikacji, który będzie zawierał informacje i funkcje dla podmiotów świadczących usługi dostępu do rachunku. Projekt Komisji Europejskiej ma zwiększyć zaufanie oraz jakość usług odnośnie do alternatywnych źródeł finansowania ${ }^{57}$.

Dla założycieli platform ważną kwestią jest ustalenie modelu crowdfundingu, jaki platforma ma przyjąć, ponieważ od tego będzie zależeć, w jakim stopniu operator będzie podlegał ustawie o przeciwdziałaniu praniu pieniędzy $i$ finansowaniu terroryzmu z 16 listopada $2000 \mathrm{r}^{58}$, gdyż dotyczy ona wszelkich działań opartych na pośrednictwie przekazywania pieniędzy. Najpowszechniejszy rodzaj crowdfundingu w Polsce bazuje na darowiznach i nagrodach i nie wymaga prowadzenia działalności regulowanej, dlatego też nie obejmuje go ustawa o praniu pieniędzy.

Inaczej przedstawia się sytuacja w przypadku platform opartych na akcjach, pożyczkach lub prowadzeniu działalności dewizowej, których działalność ma charakter instytucji finansowej. Mają one obowiązek stosowania środków zapobiegawczych przeciwko praniu pieniędzy i finansowaniu terroryzmu ${ }^{59}$.

Na mocy ustawy o świadczeniu usług elektronicznych z dnia 18 lipca $2002 \mathrm{r}^{60}$ operatorzy platform crowdfundingowych są zobowiązani do przestrzegania rozporządzenia o ochronie danych osobowych, które w Polsce obowiązuje od 25 maja 2018 r. ${ }^{61}$ Polscy crowdfunderzy mogą również podlegać ustawie o kredycie konsumenckim z dnia 12 maja $2011 \mathrm{r}^{62}$, w przypadku gdy usługi świadczone przez platformy crowdfundingowe przypominają kredyt konsumencki w rozumieniu polskiego kodeksu cywilnego.

To, jakie prawo regulacyjne będzie obowiązywało daną platformę, zależy od miejsca zarejestrowania siedziby firmy. Firmy zarejestrowane w Polsce obowiązuje polskie prawo regulacyjne. Polskiemu prawu mogą również podlegać zagraniczne platformy, które są ukierunkowane na polski rynek, tzn. oferta, jaką przekazują jest zorientowana na polskich konsumentów. Decyzję, czy taka platforma będzie zobligowana przestrzegać polskiego prawa, podejmuje Komisja Nadzoru Finansowego.

Zagraniczne platformy, które chcą pozyskać polskich inwestorów, muszą przestrzegać ogólnego rozporządzenia o ochronie danych (RODO). Platformy zarejestrowane na terenie UE obowiązuje Traktat o funkcjonowaniu Unii Europejskiej

57 Komunikat Urzędu Komisji Nadzoru Finansowego z 12 stycznia 2018 r. dotyczący wybranych oczekiwań nadzorczych w odniesieniu do okresu przejściowego związanego z implementacją Dyrektywy PSD2.

58 Ustawa z dnia 16 listopada 2000 r. o przeciwdziałaniu praniu pieniędzy oraz finansowaniu terroryzmu (Dz.U. z 2000 r. Nr 116, poz. 1216).

59 ECN Country Crowdfunding Factsheet - Poland, 2018, http://eurocrowd.org/wp-content/ blogs.dir/sites/85/2018/06/CF_FactSheet_Poland_June2018.pdf (dostęp: 10 października 2018).

60 Ustawa z dnia 18 lipca 2002 r. o świadczeniu usług drogą elektroniczną (Dz.U. z 2002 r. Nr 144, poz. 1204).

61 Ustawa z dnia 10 maja 2018 r. o ochronie danych osobowych (Dz.U. z 2018 r. poz. 1000).

62 Ustawa z dnia 12 maja 2011 r. o kredycie konsumenckim (Dz.U. z 2011 r. Nr 126, poz. 715). 
(TFUE) $^{63}$, który pozwala korzystać z podstawowych zasad swobody przedsiębiorczości i swobody świadczenia usług.

W sytuacji gdy polska platforma crowdfundingowa wejdzie na rynki zagraniczne, a co za tym idzie, będzie nastawiona na zagranicznych inwestorów, nie będzie podlegać polskim regulacjom. Operatorzy platform będą musieli spełniać wymagania licencyjne oraz przestrzegać przepisów obowiązujących w danym kraju. Ustawa o ofercie publicznej wymaga, aby twórcy platform przedstawili prospekt emisyjny, kiedy działalność platformy jest nastawiona na rynek polski ${ }^{64}$.

\section{Podsumowanie}

Crowdfunding jest stosunkowo nowym zjawiskiem, które ciągle się zmienia i ewoluuje. Nie wykształcono jeszcze jego ostatecznej wersji. Przykuwa on coraz więcej uwagi naukowej, a jego teoretyczna strona rozwija się wraz z liczbą prac napisanych na ten temat. Liczba platform crowdfundingowych ciągle rośnie, a ich założyciele korzystają z nowych modeli biznesowych. Coraz więcej projektów $\mathrm{z}$ różnorodnych dziedzin jest realizowanych przy pomocy crowdfundingu.

Crowdfunding jest formą finansowania społecznościowego, która pozwala budować społeczność na poziomie lokalnym, regionalnym oraz transgranicznym. Taki rodzaj finansowania zewnętrznego jest atrakcyjnym sposobem gromadzenia funduszy dla MŚP, start-upów i projektów typu non profit. Ten alternatywny model finansowania umożliwia lokowanie kapitału w przedsięwzięcia, które z uwagi na duże ryzyko nie mogłyby zostać sfinansowane tradycyjnymi formami. Dzięki temu crowdfunding ma szanse stać się motorem napędowym w aspekcie gospodarczym oraz społecznym, na poziomie zarówno lokalnym, jak i globalnym. Crowdfunding charakteryzuje oddolny charakter, ponieważ tworzą go zwykli ludzie, a nie profesjonalne podmioty z sektorem bankowym lub inwestycyjnym. Dzięki temu może się on ciągle zmieniać. Jest to możliwe dzięki internetowi, na którym crowdfunding opiera swoją działalność i któremu zawdzięcza swoją wolność. Niestety swoboda ta jest także źródłem zagrożeń dla crowdfundingu, ponieważ brak regulacji może prowadzić do nadużyć i oszustw. Głównym wyzwaniem dla sektora alternatywnego finansowania jest system regulacyjny, który jest niejednolity. W krajach Unii Europejskiej istniejące systemy prawne znacznie się od siebie różnią. W wielu krajach prawo regulujące crowdfunding nie istnieje lub pozostaje w stagnacji, co ogranicza rozwój alternatywnego rynku finansowego w tych jurysdykcjach. Komisja Europejska podjęła się próby ujednolicenia i harmonizacji prawa w Unii Europejskiej oraz w Europejskim Obszarze Gospodarczym, mając na celu przyspieszenie rozwoju crowdfundingu na poziomie unijnym.

\footnotetext{
63 Wersja skonsolidowana Traktatu o funkcjonowaniu Unii Europejskiej, eur-lex.europa.eu (dostęp: 15 listopada 2018).

${ }^{64}$ ECN Country Crowdfunding Factsheet...
} 
Ze względu na początkowe stadium rozwoju oraz małą skalę zjawiska trudno sprecyzować, jakich regulacji polski crowdfunding będzie potrzebował. Należy jednak pamiętać, że nadmierne wprowadzanie regulacji może prowadzić do zahamowania jego rozwoju.

\section{Bibliografia}

Belleflamme P., Lambert T., Schwienbacher A., Crowdfunding: Tapping the right crowd, „Journal of Business Venturing" 2014.

Cunningham M., The JOBS Act. Crowdfunding for Small Businesses and Start-ups, New York 2012.

Dziuba D.T., Rozwój systemów crowdfundinngu — modele, oczekiwanie i uwarunkowania, „Problemy Zarządzania" 10, 2012, nr 3.

Freund R., How to overcome the barriers between economy and sociology with open innovation, open evaluation and crowdfund-ing?, „In International Journal of Industrial Engineering and Management" 1, 2010, nr 3.

Gerber E., Kuo P. Y., Design principles. crowdfunding as a creativity support tool, [w:] Proceeding CHI '12 Extended Abstracts on Human Factors in Computing Systems, New York 2012.

Hemer J., A Snapshot on crowdfunding, „Arbeitspapiere Unternehmen und Region” 2, 2011.

Alberg T. et al., State of entrepreneurship adress: 'Financing entrepreneurial growth', „SSRN Electronic Journal" 02.2013.

Larralde B., Schwienbacher A., Crowdfunding of small entrepre-neurial ventures, „Handbook of Entrepreneurial Finance" New York 2012.

Marcinoska L. et. al., Raport: Crowdfunding, Warszawa 2014.

Mazurek-Łopacińska K., Sobocińska M., Crowdsourcing i crowdfounding w kreowaniu innowacji w konsumpcji, „Studia i Prace Wydziału Nauk Ekonomicznych i Zarządzania” 2, 2016, nr 43.

Miller K.D., Fabian F., Lin S.-J., Strategies for online communities, „Strategic Management Journal” 30, 2009.

Mollick E., Swept Away by the Crowd? Crowdfunding, Venture Capital, and the Selection of Entrepreneurs, Pennsylvania 2013.

Ordanini A. et al., Crowdfunding: Transforming customers into investors through innovative service platforms, „In Journal of Service Management” 22, 2011, nr 4.

Review of Crowdfunding Regulation 2017. Interpretations of Existing Regulation Concerning Crowdfunding in Europe, North America and Israel, red. O. Gajda, Brussels 2017.

Scholz N., The Relevance of Crowdfunding The Impact on the Innovation Process of Small Entrepreneurial Firms, Manchester 2015.

Zhang B. et al., Sustaining Momentum: The 2nd European Alternative Finance Industry Report, Cambridge 2016.

Ziegler T. et al., Expanding Horizons: The 3rd European Alternative Finance Industry Benchmarking Report, Cambridge 2016.

\section{Wykaz aktów normatywnych}

Commision Staff Working dokument, Crowdfunding in the EU Capital Markets Union, Brussels 2016, https://ec.europa.eu/transparency/regdoc/rep/10102/2016/EN/10102-2016-154-EN-F1-1.PDF.

European Comission, Executive Summary: Identifying market and regulatory obstacles to cross-border development of crowdfunding in the EU, 2017, https://ec.europa.eu/info/sites/info/files/171216crowdfunding-executive-summary_en.pdf. 
European Commission, Legislative proposal for an EU framework on crowd and peer to peer finance, Brussels 2018, https://ec.europa.eu/info/law/better-regulation/initiatives/ares-2017-5288649_en.

Komunikat Urzędu Komisji Nadzoru Finansowego z 12 stycznia 2018 r. dotyczący wybranych oczekiwań nadzorczych w odniesieniu do okresu przejściowego związanego z implementacją Dyrektywy PSD2 .

Ustawa z dnia 29 sierpnia 1997 r. Prawo bankowe (Dz.U. 2018.0.2187).

Ustawa $\mathrm{z}$ dnia 16 listopada $2000 \mathrm{r}$. o przeciwdziałaniu praniu pieniędzy oraz finansowaniu terroryzmu (Dz.U. z 2000 r. Nr 116, poz. 1216).

Ustawa z dnia 18 lipca 2002 r. o świadczeniu usług drogą elektroniczną (Dz.U. z 2002 r. Nr 144, poz. 1204).

Ustawa z dnia 27 maja 2004 r. o funduszach inwestycyjnych i zarządzaniu alternatywnymi funduszami inwestycyjnymi (Dz.U. z 2004 r. Nr 146, poz. 1546).

Ustawa z dnia 29 lipca 2005 r. o obrocie instrumentami finansowymi (Dz.U. z 2005 r. Nr 183, poz. 1538).

Ustawa z dnia 12 maja 2011 r. o kredycie konsumenckim (Dz.U. z 2011 r. Nr 126, poz. 715).

Ustawa z dnia 19 sierpnia 2011 r. o usługach płatniczych (Dz.U. z 2011 r. Nr 199, poz. 1175).

Ustawa z dnia 10 maja 2018 r. o ochronie danych osobowych (Dz.U. z 2018 r. poz. 1000).

Wersja skonsolidowana Traktatu o funkcjonowaniu Unii Europejskiej, eur-lex.europa.eu.

\section{Źródła internetowe}

ECN Country Crowdfunding Factsheet - Poland, 2018, http://eurocrowd.org/wp-content/blogs. dir/sites/85/2018/06/CF_FactSheet_Poland_June2018.pdf.

https://ec.europa.eu/info/law/better-regulation/initiatives/.

https://ec.europa.eu/info/sites/info/files/.

https://ec.europa.eu/transparency/regdoc/.

http://eurocrowd.org/wpcontent/blogs.dir/sites/.

https://koalicjadlainnowacji.pl/publikacje/. 